AGRARIS: Journal of Agribusiness and Rural Development Research

Vol. 6 No. 1 January-June 2020

Article History :

Submitted : April 9 $9^{\text {th }}, 2020$

Accepted : May $8^{\text {th }}, 2020$
Malose M. Tjale ${ }^{1}$, Marizvikuru Mwale ${ }^{*}$, Beata M. Kilonzo

University of Venda, Institute for Rural Development, South Africa

*)Correspondence email: marizvikuru.manjoro@univen.ac.za

\title{
Satisfaction of Restituted Farms Beneficiaries with Performance of Farms in Waterberg District, South Africa
}

\author{
DOI: https://doi.org/10.18196/agr.6188
}

\begin{abstract}
South African government guided by the Restitution of Land Rights Act 22 of 1994, implemented land restitution as one of the pillars of land reform programme. The mandate was to promote land ownership and equality between white and black people. This study determined the extent to which farm beneficiaries are satisfied with the performance of the restituted farms in Waterberg District. Quantitative approach was used to examine closed-ended data using stratified random sampling procedure. Interviews, photo-voice and non-participatory observation methods were additionally used to collect data through qualitative approach. The Statistical Package for the Social Sciences (SPSS version 25) was used to compute descriptive statistics and cross-tabulations while content analysis was used for the qualitative data. The study revealed that participation in the restituted farms was dominated by males $(73.0 \%)$. About 77 $\%$ of the farm beneficiaries were not satisfied with the performance of the farms and $60.5 \%$ of them confirmed that their livelihoods were not changed due to lack of farm income. Moreover, $(90.3 \%)$ reported that farms did not create job opportunities for beneficiaries. It is recommended that intervention strategy, be implemented to enhance farm performance that will satisfy farm beneficiaries.
\end{abstract}

Key words: Farm beneficiary, farm performance, land restitution, livelihoods, satisfaction

\section{INTRODUCTION}

Many countries such as Brazil, India, Zimbabwe, Kenya and South Africa have implemented land reform policies and programmes to address challenges like poverty, inadequate agricultural farm performance and inequality, especially in rural areas (Luwanda \& Stevens, 2015). In support of the above statement, Mafa, Gudhlanga, Manyeruke, Matavire, \& Mpofu (2015) indicate that land is very important because it is the core for agricultural production in the sub-region. As such disadvantaged people deserve agricultural land. Furthermore, land policies were implemented to ensure that farm beneficiaries are satisfied with the performance of the farms. In Brazil for example, "viable family smallholder farms policy" that received government support was implemented", however, the policy focused on the domestic market, while large-scale commercial farms served export markets (Erlank, 2014). 
Thus, family smallholder farms could not grow quickly enough to enhance livelihoods of the people, as more attention was given to large commercial farms to serve the export market.

The "ceiling reforms" system of India that was implemented, impacted on economic growth while asset accumulation tended to diminish over time (Deininger, Jin, \& Nagarajan, 2009), and the poor farm beneficiaries did not benefit more from ceiling legislation. In Zimbabwe the government also introduced the Fast Track Land Reform Programme (FTLRP) in 2000 to redistribute land to the peasants and working people (Moyo, 2013), however, Dugmore (2012) confirmed that agricultural production declined especially in the communal and settled areas dominated by small-scale farmers. The decline in agricultural production contributed to high unemployment rate estimated at 90\% in Zimbabwe, with a collapsed economy because of the restituted farms that were not being utilised (Dugmore, 2012). Kenya changed the property rights post-independence, where land holdings were privatized to benefit the pastoral inhabitants of the East African rangelands (Galaty, 2013). However, land reform that was implemented was based on complex economic development policies influenced by western models, whereby the poor farm beneficiaries at the local levels failed to benefit (Lesorogol, 2010).

In order to redress the colonial policies of imbalances in land reform and also mitigate the challenges of land dispossession, some interventions have been put in place to deal with land reform challenges mentioned above. A survey conducted by the Rural Support Service (RSS) in Latvia, confirmed that unused agricultural land in 2014 was 294 thousand hectares accounting for $12 \%$ of the total agricultural land (Parsova \& Kapostins, 2015). Most of the land was not used for effective agricultural production. The research gap identified is that land restitution Act 22 of 1994 was criticised in South Africa for not contributing to socioeconomic development to change lives of the restituted farms' beneficiaries. Under the land restitution initiative, black people are given back the property that was taken away from them under apartheid legislation. However, the allocated land is not utilised to benefit the farm beneficiaries (Mutanga, 2011). The current study was, accordingly, based on the hypothesis that "farm beneficiaries are not satisfied with the performance of the restituted farm".

Although land reform has played a vital role in development of people in rural areas in the country, lack of farming skills as one of the challenges among the farm beneficiaries undoubtedly led to farm performance challenges in South Africa. Hence, the impetus to conduct the current study to determine the extent to which the farm beneficiaries are satisfied with the performance of the restituted farms, and to necessitate change in land restitution policies that could bring more income into the farms, in order for beneficiaries in South Africa to receive income benefits to satisfy their socio-economic status now and in future.

\section{METHODOLOGY}

The study was conducted between July 2016 and May 2017 whereby two research paradigms were used for the study. The first was emancipatory research paradigm using quantitative approach with closed-ended responses to investigate the satisfaction of the restituted farms' beneficiaries regarding performance of the farms. The paradigm provided data on how beneficiaries make collective decisions that could inform individuals and group 
action to improve the lives of the beneficiaries. A positivist paradigm was also used to focus on quantitative study relating instruments used to collect data to avoid potential bias and error. Structured questionnaire was used to collect data through one-on-one interview. Nonparticipatory observation was used to observe day-to-day activities, such as farm production and commitment to farming. Photo-voice method was similarly used to collect data through photography whereby beneficiaries took photos on their own and convene for discussion. To enhance the reliability of the study results, triangulation of research approaches, data collection methods and tools was applied. Triangulating data from multiple data collection sources within one design Fusch, Fusch, \& Ness (2018), was achieved through asking same questions using three different data collection tools.

\section{Study Area}

The study was conducted at Waterberg District which is located within the Limpopo Province of South Africa. The District shares boundaries with Botswana to the north-west of the District. To the north-east is the Capricorn District Municipality, to the east is the Greater Sekhukhune District Municipality, Gauteng province to the south of the Waterberg District and North West Province in the south-west side. There are six towns and 10 townships within the District (Waterberg District Municipality Integrated Development Program (IDP), 2018). The unemployment rate is higher in the District at $28.1 \%$, which is closer to $29.1 \%$ of the entire country Statistics South Africa (2019). The District municipality consists of six local municipalities with 79 wards (Waterberg District Municipality IDP, 2018). The local municipalities are Mogalakwena, Mookgophong, Modimolle, Belabela, Thabazimbi and Lephalale, and most of the farms are predominantly in Mogalakwena and Mookgophong. (Waterberg District Municipality IDP, 2018). Out of 79 wards in the District, focus was given to wards with restituted farms (Figure 1).

\section{Population and Sampling Methods}

The target population was 4409 constituting farm beneficiaries and farm executive members. Stratified sampling method was used to select 448 participants in which 64 were executive members of the farms; one chairperson and one secretary from each of the 32 farms while 384 were mere farm beneficiaries.

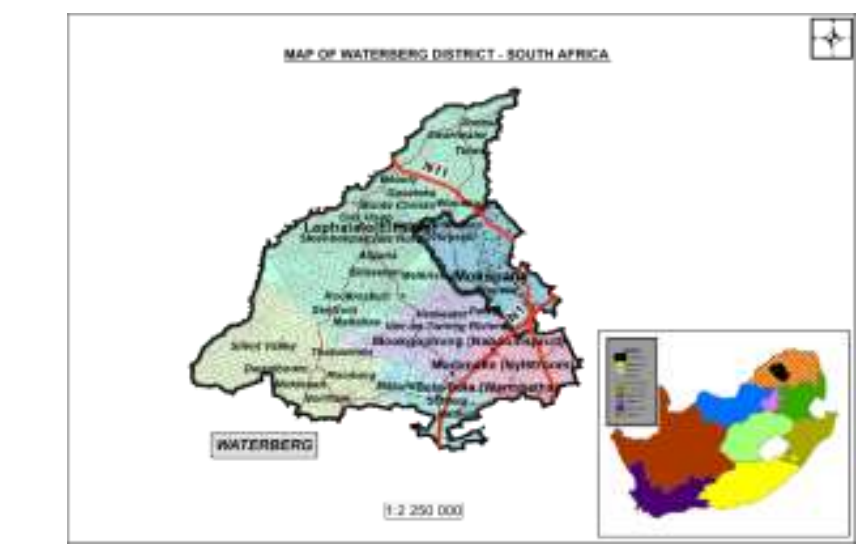

Source: Waterberg District Municipality IDP (2018)

FIGURE 1. MAP OF WATERBERG DISTRICT IN LIMPOPO PROVINCE OF SOUTH AFRICA 


\section{Data Collection}

Data was collected from 289 respondents. These were 32 chairpersons of the farms, 32 secretaries, and 225 farm beneficiaries from the restituted farms. Moreover, a photo-voice was used where farm beneficiaries took photographs of their own farms and discussed them with the view of finding solutions to the challenges they are facing. Observation was also conducted on the farms during the interviews to confirm the status of the farms and study behaviours of the farm beneficiaries on the farms.

\section{Data Analysis}

Statistical Package for the Social Sciences (SPSS version 25) was used to compute descriptive statistics and cross-tabulations of quantitative data. Furthermore, photo-voice data as well as observation data were transcribed, so that farm beneficiaries could as a collective, analyse photos and voices to bring meaning or solutions to their challenges.

\section{Ethical Considerations}

The ethics adhered to include confidentiality and respect when collecting data in particular when taking photos, information was not divulged to different farm beneficiaries unless consent had been sought. The researcher and the beneficiaries agreed by signing a consent form that the photos taken should be published only to serve the purpose of the study. Avoiding harm to respondents during research was one of the ethics considered. Added to this, the institutional ethical clearance was secured from the University of Venda Research Ethics Committee (UVREC). The clearance number was SARDF/16/IRD/07/2904. The researcher informed the participants about the research objectives, the expected outcomes and the intentions of the researcher.

\section{RESULT AND DISCUSSIONS}

In South Africa, the land reform programme was implemented in the past 26 years, with the need to redress the past historical and socio-economic injustice on land ownership imposed on the people by the former apartheid form of government (Mabuza, 2016). This land reform programme was implemented in Waterberg District and the entire South Africa. Land dispossession prior 1994, produced negative consequences in South Africa which included unproductive land, inequitable distribution of land ownership largely in favour of the white minority, and dislocation of social and economic systems of the indigenous people in relation to land use (Land Reform Policy Discussion Document, 2012). Consequently, the South African government has shown commitment to eradicate the inequalities and injustices of the past, and has initiated land reform programme (Kloppers \& Pienaar, 2014). Generally, the impact of restituted farms as part of land reform programme in South Africa is not realized. The Lisbon Estate in Mpumalanga Province is an example that has proved to be a failure (Mutanga, 2011). The Estate used to export citrus fruits and mangoes as well as employing over 2000 workers. Currently, the entire Estate is now a grazing land with dilapidated infrastructure. 
An empirical study was undertaken in KwaZulu-Natal Province to compare the output of the sugar farmland prior and after transfer to smallholder farmers in Uthungulu and iLembe areas; results showed that, half of the farms have reduced productivity 'during the year of takeover' (Van Royen, 2008). Moreover, most of the land recipients have had their land or farms back for more than ten years, yet they have not attained the anticipated socio-economic benefits such as improved livelihoods (Kloppers, 2014). The benefits from land restitution have fallen far short of public expectations when restituted farms were taken back to its original owners in South Africa, and restituted farm beneficiaries suffered more than before receiving the farms. As such, the current study was undertaken to determine the satisfaction of resituted farm beneficiaries in Waterberg District of Limpopo Province, South Africa. The results were presumably to lay foundation for devising an intervention strategy to improve productivity and hence livelihoods or restituted farm beneficiaries. The results of the current study are presented and discussed below.

\section{Gender representation at Restituted Farms}

The government of South Africa supports land restitution programmes that empower women in the rural areas, who are regarded as the pillars in the households, to participate in land reform projects. Although this is the aim, the results of this study reveal that males (73.0 $\%$ ) were the dominant participants in the restituted farms as compared to their female counterparts (27.0\%). Reagrding participation of beneficiaries in restituted farms in terms of gender, one of the principles of land reform is to ensure that women are prioritised in land reform projects (Maboa, 2014), however, the study reflected the skewedness in terms of women participation in income generation, land reform projects and employment opportunities in the restituted farms. Men are still in the majority at the restituted farms. This shows that women experience more land acquisition challenges than their male counterparts because women have limited access to information pertaining to land. Added to this, women do not have access to credit which discouraged them to participate in the restituted farms. The government of South Africa, hence, should encourage more women to participate in the restituted farms by supporting them with more funds and access to land.

\section{Quality of the Products}

Close to half $(43.9 \%)$ of the respondents indicated that products were poor and likewise, they were not suitable for agricultural markets (Table 1). The photographs in Figure 2 below are showing cattle that over-grazed more than a hector of land at Die Hoop farms. Another photograph shows cabbages at Lethlakaneng CPA that were not good for the market. This indicated clearly the lack of farming skills among the farm beneficiaries. However, 21.8 $\%$ respondents were of the opinion that products were of moderate quality because some products could be sold. About $16 \%$ indicated that their products were very good while 18.3 $\%$ confirmed that their products were good. Beneficiaries who confirmed that their products are very good, are those who used farming experience that they gained while they were under the control of the former white farm owners. 
Table 1: Quality of the Farm Products

\begin{tabular}{lrr}
\hline Response & Frequency & Proportion (\%) \\
\hline Very good & 46 & 15.9 \\
Good & 53 & 18.3 \\
Moderate & 63 & 21.8 \\
Poor & 127 & 43.9 \\
Total & 289 & 100.0 \\
\hline
\end{tabular}

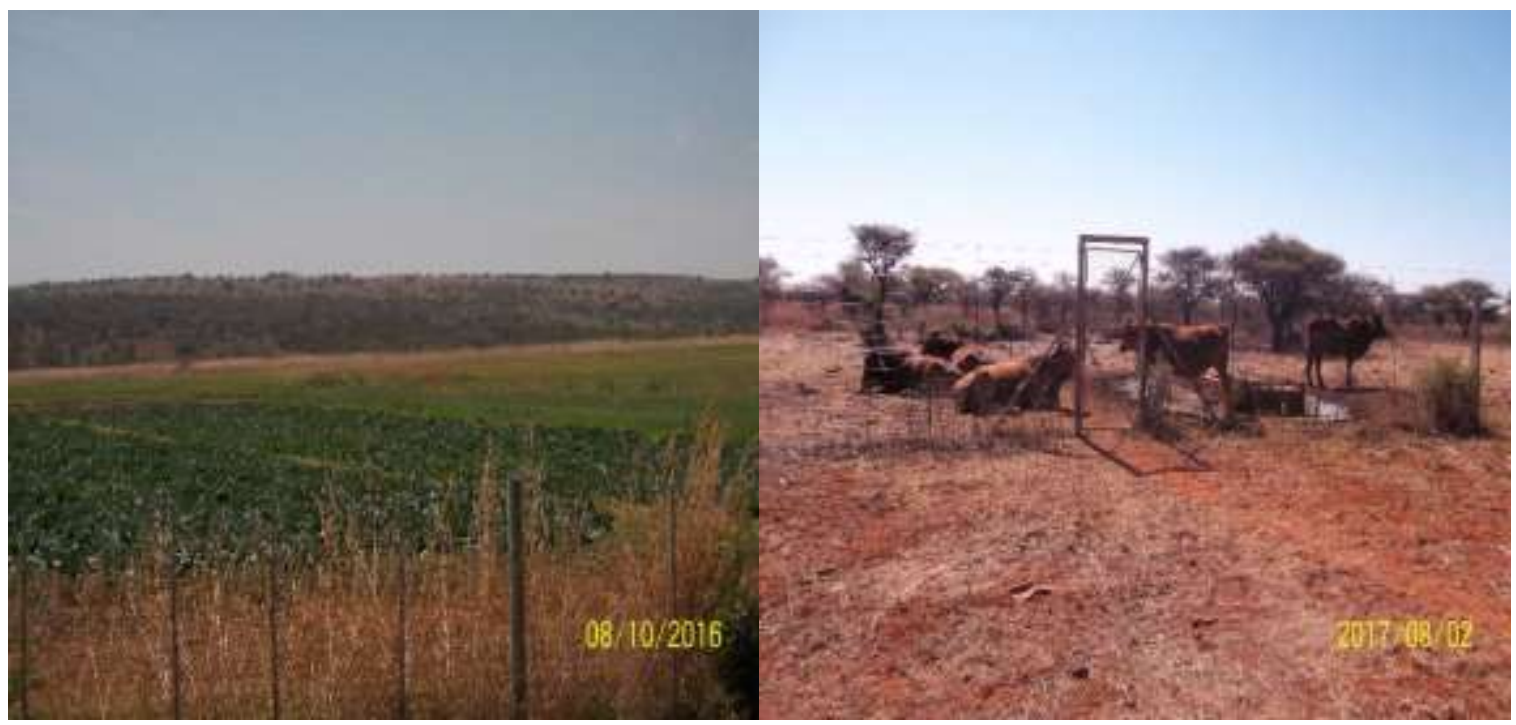

FIGURE 2: PHOTOGRAPHS SHOWING POOR UTILISATION OF THE FARM AT LETHLAKANENG FARM WITH POOR CABBAGES AND OVER-GRAZING BY CATTLE AT DIE HOOP FARM IN BELABELA MUNICIPALITY

Despite interventions brought by the land restitution programme, poverty and the socio-economic status of the restituted farm beneficiaries, has not been transformed. Majority of people agreed to the fact that performance of the restituted farms was not satisfactory and their livelihoods remained the same. The farm beneficiaries claimed that they are suffering more now than before receiving restituted farms. In Limpopo Province, farm production in some restituted farms was stopped due to misunderstanding and quarrels among farm beneficiaries. In support of this, Daniels et al. (2014) proved the unsuccessful outcomes of land reform projects in three rural communities, namely, Mashishimale (Limpopo Province), Momphela (Kwazulu-Natal) and Ebenhaeser (Western Cape). These three rural communities are located in areas that are suitable for agriculture, however, it was found that beneficiaries preferred employment than farming activities. This automatically discouraged farm beneficiaries from participating in the restituted farms because there were no tangible benefits that they received from the farms.

Quality of products is one of the four core aspects of marketing in all organisations, including the restituted farms, yet, most farm beneficiaries indicated that quality of produce on their farms was very poor. A clear indication of this is that, there would not be any income from the farms; this would compromise the benefits that farm beneficiaries were supposed to receive from farm proceeds. The photographs in Figure 2 above indicate the poor quality of the products that were produced within the two mentioned farms. In the majority of the 
restituted farms, it was observed that nothing was taking place with regard to production except a few farms across the Waterberg District, hence, it is critical to note that improved access to input and output markets is a key precondition for the transformation of the agricultural sector from subsistence to commercial production (Salami et al., 2010). According to Operation Phakisa Programme (OPP) (2016), rural areas generally suffer from "thin" markets, while the formal market structures at the national level tend to shut new and small producers out of the richer areas of the country. In turn, limited local demand makes it less worthwhile for private investors and producers to set up marketing institutions in rural areas to assist farmers with marketing their products.

Similar scenario of poor marketing of products was experienced in Ethiopia, Kenya, Tanzania and Uganda where agriculture is the backbone of their economies. These countries are in East Africa where agriculture is dominated by smallholder farmers who occupied the majority of the land and produced most of the crop and livestock (Salami et al., 2010). However, the countries are still grappling with marketing of both agricultural inputs and outputs, with markets not adequately equipped to serve the needs of the poor (Salami et al., 2010). If the farmers are more experienced, they would be able to produce more products that are good for the market. Therefore, the government, private sectors and other stakeholders should consider farming skills development in restituted farm beneficiaries.

\section{Cross tabulation for Age of farm beneficiaries and farm income generated per month}

Most respondents (64.3\%; Table 2) indicated that there was no income generated on the farms, raising issues such as lack of production inputs, equipment and finance to kick start production process. The trends on the income of the restituted farms also indicated that farms were not generating income. About $22 \%$ respondents generated between R500 and R20 000 (\$41.87 - \$1675.04@1USD=11.94 ZAR) while 5.8\% respondents indicated that their farms generated R20 000-R50 000 (1 675.04- \$ 4 187.60); $4.1 \%$ of the farm beneficiaries confirmed that their farms generated between R50 000 and R100 000 (4 187.60-\$ 8375.20 @ $1 \mathrm{USD}=11.94$ ZAR), while $3.8 \%$ generated R100 000 and above (8 375.20 and above @ $1 \mathrm{USD}=11.94 \mathrm{ZAR})$. Of the $64.3 \%$ who do not generate income, majority are the elderly (more than 50 years; Table 3.) while few are youth (less than 20 years and between 26 and 30 years old).

Farm income generated in the farms was insufficient to run the day-to-day farm activities. This affected even 19 youth aged between 20 and 35, indispensable for restituted farms sustainability. In Namibia, Werner (1999) found that none of the settlement projects older than four years have achieved self-sufficiency to provide income and furthermore, all the farms depended heavily on the government. 
TABLE 2: FARM INCOME IN RANDS AND US DOLLARS PER MONTH

\begin{tabular}{|c|c|c|c|c|c|}
\hline \multicolumn{2}{|c|}{ Income in Rand (ZAR) } & \multicolumn{2}{|c|}{$\begin{array}{l}\text { Income in US dollars (US\$) @ IUSD= } 11.94 \\
\text { ZAR exchange rate }\end{array}$} & \multicolumn{2}{|l|}{ Proportion of respondents } \\
\hline No income at all & & \multicolumn{2}{|l|}{ None } & \multicolumn{2}{|l|}{64.3} \\
\hline $500-20000$ & & \multicolumn{2}{|l|}{41.87 - US\$ 1675.04} & \multicolumn{2}{|l|}{21.7} \\
\hline $20000-50000$ & & \multicolumn{2}{|l|}{1 675.04-- US\$ 4187.60} & \multicolumn{2}{|c|}{5.8} \\
\hline $50000-100000$ & & \multicolumn{2}{|l|}{4 187.60- US\$ 8375.20} & \multicolumn{2}{|c|}{$\begin{array}{l}4.1 \\
38\end{array}$} \\
\hline 100000 and above & & \multicolumn{2}{|l|}{ US\$ 8375.20 and above } & \multicolumn{2}{|l|}{3.8} \\
\hline \multicolumn{4}{|l|}{ Total } & \multicolumn{2}{|c|}{100} \\
\hline \multicolumn{6}{|c|}{ TABLE 3: CROSS TABULATION FOR AGE CATEGORIES OF BENEFICIARIES AND FARM INCOME GENERATED PER MONTH } \\
\hline Age & No income & $\begin{array}{c}\text { R500 - R20 000 } \\
\text { (US\$41.87-- US\$ } 1 \\
675.04 \text { ) }\end{array}$ & $\begin{array}{l}\text { R20 } 000-\text { R50 } 000 \\
\text { (US\$ } 1675.04- \\
\text { US\$ } 4 \text { 187.60) }\end{array}$ & $\begin{array}{c}\text { R50 000-R100000 } \\
\text { (US\$ } 4 \text { 187.60- US\$ } 8 \\
375.20)\end{array}$ & Total \\
\hline $\begin{array}{l}\text { Less than }(20 \\
\text { years) }\end{array}$ & 2 & 0 & 0 & 0 & 2 \\
\hline $20-25$ & 8 & 3 & 2 & 0 & 13 \\
\hline $26-30$ & 1 & 1 & 0 & 0 & 2 \\
\hline $31-35$ & 8 & 2 & 0 & 2 & 12 \\
\hline $36-40$ & 5 & 2 & 0 & 0 & 7 \\
\hline $41-45$ & 28 & 2 & 2 & 1 & 33 \\
\hline $46-50$ & 12 & 5 & 2 & 1 & 20 \\
\hline More than 50 & 122 & 48 & 11 & 19 & 200 \\
\hline Total & 186 & 63 & 17 & 23 & 289 \\
\hline
\end{tabular}

Jobs created for the farm beneficiaries

About $90.3 \%$ (261) respondents indicated that restituted farms created less than 50 jobs during the period 2005 to 2015. Most of the farm beneficiaries who confirmed that less than 50 jobs were created up to 2015 were youth aged between 20 and 35 . The reasons stated by the farm beneficiaries were that farms have not been operating since occupation, while other farms were abandoned because of internal fights. On the other hand, $7.9 \%$ of the farm beneficiaries aged between 36 and 45 confirmed that their farms have created between 50-100 jobs (Figure 3). Interestingly, elderly farmers (more than 50 years old) confirmed that farms had created 150 jobs and above citing that older people enjoy working in the farms even if there is no income. The issue of Restituted farms jobs creation was also discussed through photo-voice at Morongoa Community Property Association (CPA) in Lephalale area, majority of farm beneficiaries confirmed struggling to survive from the restituted farms due to shortage of jobs at the farms (Figure 4). The farm beneficiaries highlighted that restituted farms should 
be supported with sufficient funds that could boost productivity and subsequently job creation.

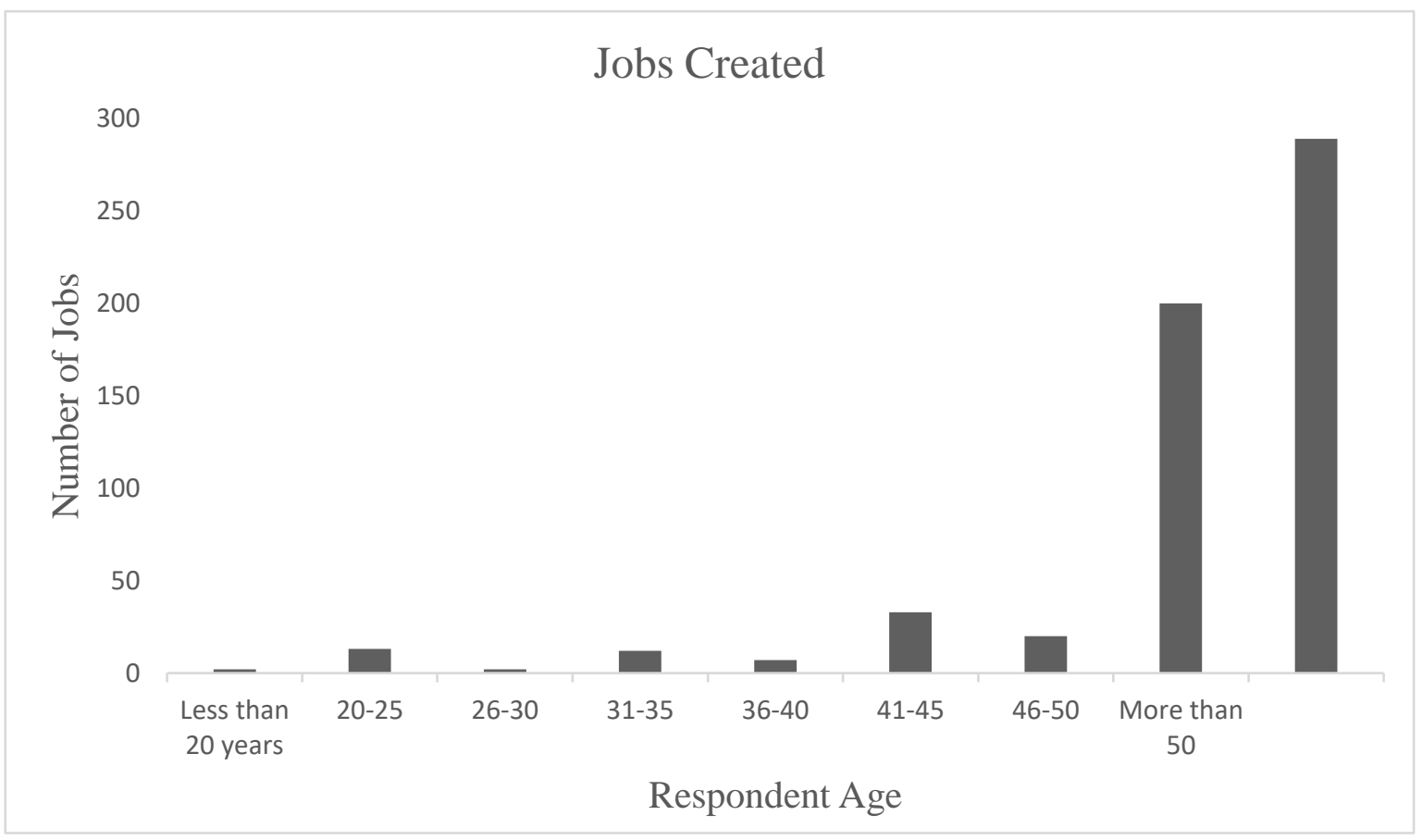

FIGURE 3: JOBS CREATED FOR THE FARM BENEFICIARIES
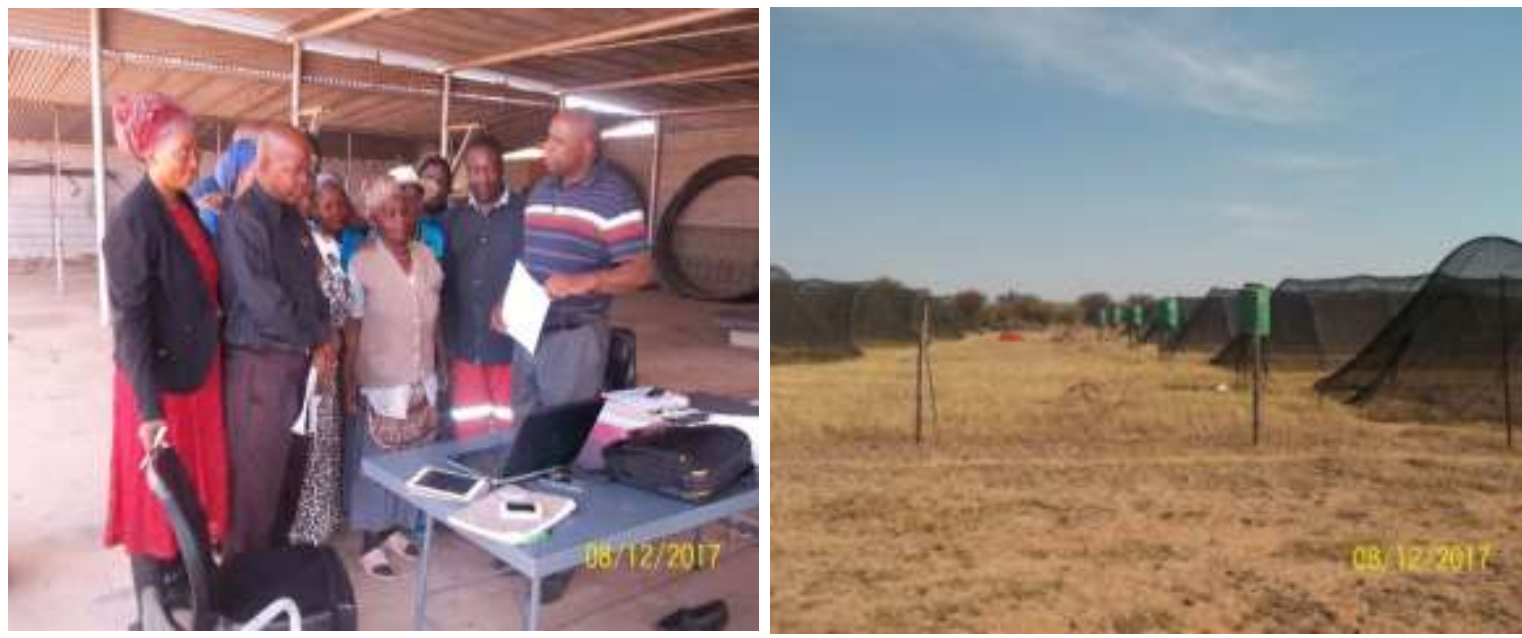

FIGURE 4: PHOTO-VOICE DISCUSSION AT MORONGOA CPA FARM IN LEPHALALE MUNICIPALITY

One of the main objectives of land reform was to alleviate poverty among farm beneficiaries through job creation within the restituted farms. However, the study revealed majority with $90.3 \%$ responded that restituted farms have not created employment for the poor beneficiaries. Although they own the farms, the farm beneficiaries remain unemployed because their farms are inactive. This is supported by Maboa (2014) that job creation in the rural economy still remains the responsibility of mostly smallholder farmers. Maboa (2014) further revealed the failure of land reform projects to create job opportunities in Elias Motsoaledi local Municipality in Limpopo Province. The majority of land reform beneficiaries 
were not working on their farms and those who were employed were working outside the farms. Contrary to the above statement, World Bank Appraisal Report (2004) revealed Venezuela as one of the countries that promoted conditions for holistic rural development to generate employment and guarantee the peasant population an adequate level of well-being as well as their incorporation into national development. All relevant stakeholders, other governments, including South Africa should imitate this good practice of supporting rural development including land restituted farms.

\section{Salaries for the farm beneficiaries}

The majority $(83.3 \%)$ of the respondents indicated that they had benefited nothing in terms of salaries or wages from the restituted farms, while $10.7 \%$ reported that they had received between R500-R1000 (\$ 41.87 -\$83.75 @ 1USD=11.94 ZAR) per month from the farms as their benefits (Table 4). The former findings were confirmed by the majority of elderly farm beneficiaries. About $4.8 \%$ cases confirmed that they receive salaries between R1000 and R5000 (83.75 - \$418.76). Few (1.0 \%) received salaries of more than R5000 (\$418.76) per month. The key finding was that the majority of the farm beneficiaries are not benefiting at the end of the month. The fact that farm beneficiaries are not satisfied with the performance of the farms makes them not believe that restituted farms could improve their livelihoods (Business Enterprise on Evaluation of recapitalisation and development programme, 2013). Also in Malawi the average of the farm incomes for beneficiary households, substantially went down two years after the phasing out of the Community Based Rural Land Development Project (CRLDP) that was implemented to assist in improving the performance of the land reform projects (Luwanda \& Stevens, 2015). Business Enterprise on Evaluation of Recapitalisation and Development Programme (2013) further mentioned that land reform programmes aimed at poverty alleviation need to incorporate farming enterprises that can generate immediate benefits that can satisfy farm beneficiaries. This would help to improve the livelihoods of the beneficiaries. Added to this, the majority of the beneficiaries who were not satisfied with the benefits from the farms, in particular different services from other departments, claimed that they received minimal support in terms of funding, non-renovation of dilapidated infrastructure, equipment, and non-provision of inputs, and that is one of the reasons why most farms were dormant. In order to address the challenges of the farm beneficiaries, there is a need for the government to prioritise the said support to the farm beneficiaries. Generally, this is also happening in most regions where the poor beneficiaries have not benefited from either the land redistributed or land restituted in terms of wages or salaries due to poor farm production. 
TABLE 4: SALARIES FOR THE FARM BENEFICIARIES

\begin{tabular}{|c|c|c|c|c|c|}
\hline \multirow[b]{2}{*}{ Respondent age } & \multicolumn{4}{|c|}{ Salary Ranges } & \multirow[b]{2}{*}{ Total } \\
\hline & Nothing & $\begin{array}{l}\text { R500- R1000 } \\
\text { (US\$ 41.87- } \\
\text { US\$ 83.75) }\end{array}$ & $\begin{array}{c}\text { R1000-R5000 } \\
\text { (US\$83.75- } \\
\text { US\$ 418.76) }\end{array}$ & $\begin{array}{c}\text { R5000 (US\$ } \\
\text { 418.76) and above }\end{array}$ & \\
\hline Less than 20 years & 2 & 0 & 0 & 0 & 2 \\
\hline $20-25$ & 8 & 4 & 1 & 0 & 13 \\
\hline $26-30$ & 1 & 0 & 1 & 0 & 2 \\
\hline $31-35$ & 10 & 1 & 1 & 0 & 12 \\
\hline $36-40$ & 7 & 0 & 0 & 0 & 7 \\
\hline $41-45$ & 26 & 4 & 2 & 1 & 33 \\
\hline $46-50$ & 18 & 1 & 1 & 0 & 20 \\
\hline More than 50 & 169 & 21 & 8 & 2 & 200 \\
\hline Total & 241 & 31 & 14 & 3 & 289 \\
\hline
\end{tabular}

\section{CONCLUSIONS}

The majority of restituted farm beneficiaries in Waterberg District were not satisfied with the performance of the restituted farms. They claim not to benefit from the farms and that their livelihoods are still the same because of the decline in production due to lack of resources and support from the government. The beneficiaries still suffer as they did before they received the farms, therefore without the intervention from the Government, the resource-constrained restituted farmers would not realize self-sustenance. The male beneficiaries were the most affected because they are the majority owners of the restituted farms as compared to females. Hence, it is imperative to conduct studies to develop an intervention strategy that will inform land restitution policies for enhanced production at restituted farms. This could ultimately improve livelihoods of the farm beneficiaries.

\section{ACKNOWLEDGEMENTS}

The researchers acknowledge the University of Venda in particular the research unit that provided financial support to undertake the study (project no: SARDF/16/IRD/07/2904), and to ensure that the paper is finally published. Furthermore, the support from the Waterberg District Municipality, Department of Rural Development and Land Reform, Department of Agriculture, House of Traditional Council and restituted farm beneficiaries is highly appreciated.

\section{REFERENCES}

Deininger, K., Jin, S., \& Nagarajan, H. K. (2009). Land reform, Poverty Reduction, and Economic Growth: Evidence from India. JDEVS: Journal of Development Studies, 45(4), 496-521. Retrieved from https:www.tandfonline.com/doi/abs/10.1080/00220380902725670. 
Erlank, W. (2014). Green paper on land reform: Overview and challenges. ELECLJ: Electronic Law Journal, 17(2), 614-639. Retrieved from https://www.saflii.org/za/journals/PER/2014/18.html

Fusch, P., Fusch, G. E., \& Ness, L. R. (2018). Denzin`s paradigm Shift (Revisiting Triangulation in Qualitative Research). JSOC: Journal of Social Change, 10(1), 19-32. Retrieved from http://www.semanticsholar.org/paper/Denzin\%E2\%80\%99s_paradigm-shift\%3AR...

Galaty, J.G. (2013). The collapsing platform for pastoralism: Land sales and land loss in Kajiado County, Kenya. JNOMP: Journal of the Nomadic People, 17(2), 20-39. Retrieved from https://www.thecommonjournal.org/articles/10.18352/ijc.720/

Kloppers, H. J. (2014). Introducing CSR (The Missing Ingredient in the Land Reform Recipe?). JPEL: Journal of Potchefstroom Electronic Law, 17(2), 708-758. Retrieved from

http://www.scielo.org.za/scielo.php?script=sci_arttex\&pid=S1727_37812014000200 002

Kloppers, H.J., \& Pienaar, G. J. (2014). The historical context of land reform in South Africa and Early Policies. JPEL: Journal of Potchefstroom Electronic Law, 17(2), 677-706. Retrieved from http://www.saflii.org/za/journals/PER/2014/20.html

Lesorogol, C.K. (2010). The Impact of Privatization on Land Inheritance among Samburu Pastoralists in Kenya. JDEVC: Journal of Development and Change, 41(6), 1091 1115. Retrieved from http://www.endvawnow.org/en/articles/767-inheritance-la

Luwanda, M. C., \& Stevens, J. B. (2015). Effects of dysfunctional stakeholder collaboration on performance of land reform initiatives (Lessons from Community Based Rural Land Development Project in Malawi). SASAE: South African Journal of Agricultural Extension, 43(1), 122-134. Retrieved from http://www.scielo.org.za/scielo.php?script=sci_artlext\&pid=S0301$603 \times 2015000100010$

Werner, W. 1999. An overview of land reform in Namibia. AGREJ: Agrekon Journal, 38, 314-325. Retrieved from http://sarpn.org/EventPaper/Land/20010604Werner.pdf

Business Enterprise, 2013. Evaluation of the Recapitalisation and Development Programme. University of Pretoria, Pretoria, South Africa. Retrieved from https://evaluationsdpme.gov.za/evaluations/407/document/5bc0b2e/-dff5-4922-9f66...

Land Reform Policy Discussion Document, 2012. Government of South Africa, Government publishers: Pretoria. Retrieved from http://www.sahistory.org..za/sites/default/files/landpolicyproposals_june2012v_

South Africa: Department of Agriculture, Land Reform and Rural Development. 2016. Operation Phakisa Programme. Pretoria, South Africa. Retrieved from http://www.daff.gov.za/daffweb3/Branches/FisheriesManagement/Aquacultureand...

Daniels, R. C., Patridge, A., Kekana, D., \& Musundwa, S. (2014). Southern Africa Labour and Development Research Unit: Rural Livelihoods in South Africa (Working Paper 
Series No: 122). University of Cape Town, Cape Town. Retrieved from http://Opensaldru.uct.ac.za/handle/11090/685

Parsova, V., \& Kapostins, E. (2015). Land Policy in Latvia: Implementation and Evaluation of results (proceedings of the 7th International Scientific Conference Rural Development 2015). Aleksandras Stulginskis University publishers, Latvia. Retrieved from

https://www.researchgate.net/publication/297659024_Land_Use_Analysis_in_Lati via_i...

Salami, A., Kamara, A. B., \& Brixiova Z. (2010). Smallholder Agriculture in East Africa (Trends, Constraints and Opportunities Working Paper Series No 105, p.20-23). African Development Bank Group, Tunisia. Retrieved from https://www.researchgate.net/publication/24759117_smallholder_Agriculture_in_ East...

Dugmore. (2012). Land reform and food security or a politically driven disaster. Rhode University publishers, Cape Town, South Africa. Retrieved from https://heatherdugmore.co.za/wp-content/uploads/2016/10/Land-publication.pdf

Maboa. (2014). Socio-economic analysis of land reform projects at Elias Motsoaledi Local Municipality in the Limpopo Province of South Africa: comparing the degree of contribution to food security. University of South Africa, Pretoria, South Africa. Retrieved from http://uir.unisa.ac.za/bitstream/handle/10500/13513/dissertation_mafora_mh.pdf ,sequ...

Mabuza. (2016). Socio-economic impact of land reform projects benefiting from the Recapitalisation and Development Programme in South Africa. University of Pretoria, Pretoria, South Africa. Retrieved from https://www.up.ac.za/food-security-policyinnovation-lab/articles/2732932/preview? mod...

Van Rooyen, J. (2008). Land Reform in South Africa: Effects on Land Prices and Productivity. Rhodes University, Grahamstown. Retrieved from htps://www.nelsonmandela.org/uploads/files/Land_law_and_leadership_paper_2p $\mathrm{df}$

Mafa, O., Gudhlanga, E.S., Manyeruke, N., Matavire, E.H.M. \& Mpofu, J. (2015). Gender, Politics and Land use in Zimbabwe-1980-2012. Senegal: CODESRIA. Retrieved from https://www.codesria.org/1MG/pdf/00prelim.pdf?4245/6f7c4d38a68e6f06517dd45992...

Moyo, S. (2013). Zimbabwe`s Fast Track Land Reform: Implications for South Africa. In The promise of land: Undoing a century of dispossession in South Africa, eds. F. Hendricks, L. Ntsebeza and K. Helliker. Auckland Park: Jacana Media. Retrieved from https://www.tandfonline.com/doi/full/10-1080/030562442019.1622210.

Mutanga, S.S. (2011). An Assessment of Livelihood Realities in the Lowveld of Zimbabwe and Natives Land Act of 1913. Pretoria: Government publishers, Pretoria. Retrieved from http://www.semanticscholar.org/paper/Access-to-land-and-land-ownership-forresde... 
IDP. (2018). Waterberg District Municipality IDP 2018. Modimolle. Retrieved from http://www.waterberg.gov.za/docs/plans/Draft\%202017-18\%201DPpdf

WBR. (2004). World Bank Appraisal report 2004. Washington DC. Retrieved from https://openknowledge.worldbank.org/bitstream/handle/10986/5986WDR\%2020 $04 \%$ 